\title{
Is it necessary to monitor the serum luteinizing hormone(LH) concentration on the human chorionic gonadotropin (HCG) day among young women during the follicular-phase long protocol? 『A retrospective cohort study
}

Wenjuan Zhang ( $\sim 2524740247 @ q q . c o m$ )

The Third Affiliated Hospital of Zhengzhou University

Zhaozhao Liu

The Third Affiliated Hospital of Zhengzhou University

Manman Liu

The Third Affiliated Hospital of Zhengzhou University

Jiaheng $\mathbf{L i}$

The Third Affiliated Hospital of Zhengzhou University

Yichun Guan

The Third Affiliated Hospital of Zhengzhou University

\section{Research Article}

Keywords: luteinizing hormone, pituitary desensitization, retrieved eggs, live birth

Posted Date: September 16th, 2021

DOI: https://doi.org/10.21203/rs.3.rs-885747/v1

License: (1) This work is licensed under a Creative Commons Attribution 4.0 International License.

Read Full License

Version of Record: A version of this preprint was published at Reproductive Biology and Endocrinology on February 2nd, 2022. See the published version at https://doi.org/10.1186/s12958-022-00888-4. 


\section{Abstract \\ Background}

The normal physiological function of LH requires a certain concentration range, but because of pituitary desensitization, even on the HCG day, endogenous levels of LH are low in the follicular-phase long protocol. So our study aimed to determine whether it is necessary to monitor serum LH concentrations and to determine whether there is an optimal LH range to achieve the desired clinical outcome.

\section{Methods}

A retrospective cohort study included 4503 cycles of in vitro fertilization (IVF)/intracytoplasmic sperm injection (ICSI) units from January 1, 2016, to June 30, 2019, in a single department. The main outcome measures included retrieved eggs, available embryos, live birth rate.

\section{Results}

Divided the $\mathrm{LH}_{\mathrm{HCG}}$ into five groups: Group A (LH $\left.\leq 0.5\right)$, Group B (0.5 IU/L $\left.<\mathrm{LH} \leq 1.2 \mathrm{IU} / \mathrm{L}\right)$, Group C (1.2 $\mathrm{IU} / \mathrm{L}<\mathrm{LH} \leq 2.0 \mathrm{IU} / \mathrm{L})$, Group D (2.0 IU/L $<\mathrm{LH} \leq 5.0 \mathrm{IU} / \mathrm{L})$, Group $\mathrm{E}(\mathrm{LH}>5 \mathrm{IU} / \mathrm{L})$. In terms of the numbers of retrieved eggs, embryos, high-quality embryos and diploid fertilized oocytes, an increase of the $\mathrm{LH}_{\mathrm{HCG}}$ level showed a trend of a gradual decrease. However, there was no significant difference in clinical outcomes among the groups.By adjusting for confounding factors, with an increase in $\mathrm{LH}_{\mathrm{HCG}}$, the number of retrieved eggs decreased.

\section{Conclusion}

In the follicular-phase long protocol among young women, monitoring of $\mathrm{LH}_{\mathrm{HCG}}$ are recommended in the clinical guidelines. What's more, those who undergo Preimplantation Genetic Testing(PGT) may benefit more when the $\mathrm{LH}$ level is controlled within a certain range.

\section{Introduction}

Appropriate protocols of controlled ovarian stimulation (COS) are critical for assisted reproductive technology (ART) outcomes. The discovery of gonadotropin-releasing hormone $(\mathrm{GnRH})$ analogs has offered multiple options in assisted reproduction and improved in vitro fertilization (IVF) success rates (1). Effective control of the premature luteinizing hormone (LH) peak, reduction of the cycle cancellation rate and more mature oocytes make the $\mathrm{GnRH}$ agonist protocol popular in many reproductive centers. In China, the follicular-phase long protocol has gradually become mainstream because of its simple and convenient single administration, good follicular homogeneity, and excellent fresh cycle outcomes (2). In 
the $\mathrm{GnRH}$ agonist protocol, because of pituitary desensitization, endogenous levels of LH are very low during the late stimulation phase (3). Moreover, approximately $50 \%$ of patients undergoing IVF/intracytoplasmic sperm injection (ICSI) using a GnRH agonist are LH deficient (3). Thus, it would seem logical that LH supplementation would be beneficial.

According to the "two-cell, two-gonadotrophin theory", both follicle-stimulating hormone (FSH) and luteinizing hormone $(\mathrm{LH})$ are important for follicle development in humans. This model explains our understanding of folliculogenesis (4). LH stimulates theca cells, promoting androgen production, and FSH regulates the proliferation of granulosa cells (GCs) and promotes E2 synthesis. Whereas FSH is the main regulator of antral follicular growth, LH plays key roles in promoting steroidogenesis and in the development of the leading follicle. Moreover, LH exerts different functions during the different stages of both natural and stimulated cycles (5). During the menstrual cycle, LH not only promotes the growth of larger follicles but also increases granulosa cell FSH activity by increasing androgen synthesis, and then LH promotes the recruitment of follicles.

The normal physiological function of $\mathrm{LH}$ requires a certain concentration range, namely, the "LH window" (6). When below the LH threshold, the eggs cannot fully mature, and there is not enough androgen and estrogen synthesis. Moreover, there is a lack of paracrine signals between granulosa cells and membrane cells. In contrast, when beyond the upper limit, granulosa cell proliferation is inhibited, which can lead to a series of problems in egg development. Therefore, we speculate that it is necessary to monitor the level of LH during the early follicular phase long protocol.

An increasing amount of evidence has demonstrated that downregulation with a $\mathrm{GnRH}$ agonist in some normogonadotrophic women may result in profound suppression of $\mathrm{LH}$, which in turn impairs adequate estradiol synthesis during FSH stimulation for IVF/ICSI (4-7), and reduces the fertilization rate (8), the number of clinical pregnancies (8), and the pregnancy outcomes (9). However, there is some controversy about this conclusion.

Consequently, this study aimed to determine whether it is necessary to monitor the serum LH concentration on the HCG day $\left(\mathrm{LH}_{\mathrm{HCG}}\right)$, to identify whether the $\mathrm{LH}$ level on the human chorionic gonadotropin $(\mathrm{HCG})$ day $\left(\mathrm{LH}_{\mathrm{HCG}}\right)$, have an impact on the clinical outcome and to determine whether there is an optimal $\mathrm{LH}$ range to achieve the expected clinical outcome.

\section{Material And Methods}

\section{Study design and participants}

The subjects of this retrospective study underwent 4503 cycles of IVF or ICSI units from January 1, 2016 to June 30, 2019 in our department. The following inclusion criteria were applied: 1) age $\leq 40$ years, 2) follicular-phase single-dose GnRH agonist protocol, 3) fresh cycle transplants, HCG endometrial thinning, recurrent miscarriage, and endometriosis. 
The study was approved by the ethics committee of the Third Affiliated Hospital of Zhengzhou University $(2021$ - 105).

Data on patient age and infertility treatment-related characteristics were collected from the files. Basic sex hormone levels (follicle stimulating hormone [FSH], luteinizing hormone [LH], estradiol [E2], progesterone $[\mathrm{P}])$, Gn dose, duration of $\mathrm{Gn}$ stimulation, number of oocytes obtained, number of oocytes retrieved, the two pronuclear zygote (2PN) embryo rate, the high-quality embryo rate, the number of embryos transferred, and the LH level on day 1 of ovarian stimulation/the HCG day were recorded. $\mathrm{E} 2 / \mathrm{P} /$ on the day of hCG administration was recorded. Clinical pregnancy was defined as visualization of both a gestational sac and fetal cardiac activity on transvaginal ultrasound. Early spontaneous abortion refers to pregnancy failure that occurred before 12 weeks.

\section{Stimulation protocols}

Follicular-phase single-dose GnRH agonist protocol: A single dose of $3.75 \mathrm{mg}$ long-acting $\mathrm{GnRH}$ agonist triptorelin (Diphereline, IPSEN, Paris, France) was administered on day 2 or 3 of the menstrual cycle. Twenty-eight days later, serum FSH, LH, E2, and $\mathrm{P}$ were examined. When $\mathrm{FSH}$ and $\mathrm{LH}$ were both $<5 \mathrm{IU} / \mathrm{L}$, $\mathrm{P}<1 \mu \mathrm{g} / \mathrm{L}$ and $\mathrm{E} 2<50 \mathrm{pg} / \mathrm{ml}$, gonadotropin (Gn) was initiated daily until ovulation induction. HMG (Livzon, China, Zhuhai) or recombinant LH (rLH Luveris Merck Serono S. A, Beijing) was added according to follicular development. When three follicles reached a mean diameter of $17 \mathrm{~mm}$ or two follicles reached a mean diameter of $18 \mathrm{~mm}, 0.25 \mathrm{mg}$ of recombinant LH (Ovidrel, Merck Serono S.A., Beijing) was administered intramuscularly. Oocyte retrieval was performed $36 \mathrm{~h}$ after hCG injection by transvaginal ultrasound-guided single-lumen/double-lumen needle aspiration. Intracytoplasmic sperm injection (ICSI) was performed only for severe male factor infertility or previous fertilization failure. Luteal phase support was initiated on day 1 after oocyte retrieval. The cleavage stage embryo transfer time was 3 days after egg retrieval. The blastocyst transfer time was 5 days after egg retrieval. Morphologic criteria were used for embryo scoring (10).

\section{Statistical analysis}

Differences in variables between the groups were statistically analyzed with Student's t-test and chisquared tests when appropriate. A bilateral $p$ value $<0.05$ was considered to be significant. The results are presented as the mean \pm standard deviation. If the variances were not uniform, we used the rank sum test for comparison.

Linear regression analysis was performed to assess the association between the LH level on the HCG day and the number of eggs retrieved, whereas logistic regression analysis was used to evaluate the correlation with the rate of conception. The same set of potential confounders was introduced into the regression models for adjustment by the enter method, regardless of whether significant differences between groups were observed. Statistical analysis was performed with the Statistical Package for the Social Sciences (version 24.0; SPSS Inc, USA). All P $<0.05$ on one-sided tests was considered to be statistically significant. 


\section{Results}

\section{The influence of $\mathrm{LH}_{\mathrm{HCG}}$ level on the outcome of IVF/ICSI-ET}

When the serum LH level is lower than $0.5 \mathrm{IU} / \mathrm{L}$, both the fertilization rate and the number of embryos decreases significantly. Some clinicians believe that the threshold of LH can be set to $1.2 \mathrm{IU} / \mathrm{L}$; if the LH is lower than this level, follicular development and endometrial growth will be severely insufficient (11). When the serum LH level is greater than $5.0 \mathrm{IU} / \mathrm{L}$ on the day of hCG in the follicular-phase long protocol, the pregnancy rate significantly decreased (12). Thus, we divided the $\mathrm{LH}_{\mathrm{HCG}}$ into five groups: Group $\mathrm{A}$ (LH $\leq 0.5)$, Group B (0.5 IU/L < LH $\leq 1.2 \mathrm{IU} / \mathrm{L})$, Group C (1.2 IU/L $<\mathrm{LH} \leq 2.0 \mathrm{IU} / \mathrm{L})$, Group D $(2.0 \mathrm{IU} / \mathrm{L}<\mathrm{LH} \leq 5.0$ $\mathrm{IU} / \mathrm{L})$, Group E (LH> $5 \mathrm{IU} / \mathrm{L})$.

There were 9 cycles with $\mathrm{LH}_{\mathrm{HCG}} \geq 10 \mathrm{IU} / \mathrm{L}$ in the follicular-phase long protocol, of which only 1 cycle was greater than $20 \mathrm{IU} / \mathrm{L}$. There was no obvious follicle luteinization in these cycles.

According to the basic information and clinical characteristics of the patients, the age of group $D$ was slightly lower than that of group C. The BMI of groups D and E was lower. The basal FSH and LH in groups $C, D$ and $E$ were higher than those in groups $A$ and $B$ (Table 1 ). 
Table 1

Patient characteristics of clinical

\begin{tabular}{|c|c|c|c|c|c|c|}
\hline & $\begin{array}{l}\text { Group } \\
\text { A(LH } \leq \\
0.5)\end{array}$ & $\begin{array}{l}\text { Group B } \\
(0.5 \text { 囚LH } \leq \\
1.2)\end{array}$ & 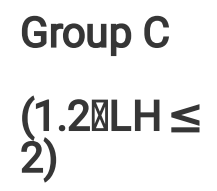 & $\begin{array}{l}\text { Group D } \\
(2 \times L H \leq 5)\end{array}$ & $\begin{array}{l}\text { Group E } \\
(\text { LH囚5) }\end{array}$ & $P$ \\
\hline No.of cycles & 225 & 2143 & 1495 & 580 & 60 & \\
\hline $\begin{array}{l}\text { Age of } \\
\text { woman(years) }\end{array}$ & $\begin{array}{l}29.80 \pm \\
3.93\end{array}$ & $\begin{array}{l}29.69 \pm \\
3.89\end{array}$ & $\begin{array}{l}29.92 \pm \\
3.82\end{array}$ & $\begin{array}{l}29.30 \pm \\
3.80^{c}\end{array}$ & $\begin{array}{l}29.65 \pm \\
3.92\end{array}$ & 0.025 \\
\hline $\begin{array}{l}\text { Body mass } \\
\text { index }\left(\mathrm{kg} / \mathrm{m}^{2}\right)\end{array}$ & $\begin{array}{l}23.91 \pm \\
3.50\end{array}$ & $\begin{array}{l}23.80 \pm \\
3.22\end{array}$ & $\begin{array}{l}23.56 \pm \\
3.17\end{array}$ & $\begin{array}{l}22.49 \pm \\
3.18^{\mathrm{abc}}\end{array}$ & $\begin{array}{l}22.52 \pm \\
3.37^{\mathrm{ab}}\end{array}$ & 0.000 \\
\hline \multicolumn{7}{|l|}{$\begin{array}{l}\text { Basic hormone } \\
\text { concentrations }\end{array}$} \\
\hline $\mathrm{FSH}(\mathrm{IU} / \mathrm{L})$ & $\begin{array}{l}6.38 \pm \\
1.86\end{array}$ & $6.64 \pm 1.90$ & $\begin{array}{l}7.06 \pm \\
2.12^{\mathrm{ab}}\end{array}$ & $\begin{array}{l}7.35 \pm \\
2.13^{\mathrm{ab}}\end{array}$ & $\begin{array}{l}7.73 \pm \\
2.33^{\mathrm{ab}}\end{array}$ & 0.000 \\
\hline $\mathrm{LH}(\mathrm{IU} / \mathrm{L})$ & $\begin{array}{l}4.89 \pm \\
3.60\end{array}$ & $5.38 \pm 3.77$ & $\begin{array}{l}5.99 \pm \\
3.90^{\mathrm{ab}}\end{array}$ & $\begin{array}{l}6.80 \pm \\
5.67^{\mathrm{abc}}\end{array}$ & $\begin{array}{l}6.71 \pm \\
4.81^{\mathrm{ab}}\end{array}$ & 0.000 \\
\hline $\mathrm{P}(\mathrm{nmol} / \mathrm{L})$ & $\begin{array}{l}145.60 \pm \\
64.69\end{array}$ & $\begin{array}{l}152.96 \pm \\
109.13\end{array}$ & $\begin{array}{l}155.76 \pm \\
146.55\end{array}$ & $\begin{array}{l}159.43 \pm \\
169.57\end{array}$ & $\begin{array}{l}164.23 \pm \\
120.90\end{array}$ & 0.615 \\
\hline E2(pmol/L) & $\begin{array}{l}1.52 \pm \\
2.17\end{array}$ & $1.42 \pm 1.79$ & $\begin{array}{l}1.45 \pm \\
3.03^{\mathrm{ab}}\end{array}$ & $1.57 \pm 3.65$ & $1.90 \pm 2.63$ & 0.000 \\
\hline $\mathrm{AMH}(\mathrm{pmol} / \mathrm{L})$ & $\begin{array}{l}37.00 \pm \\
23.12\end{array}$ & $\begin{array}{l}33.16 \pm \\
22.03\end{array}$ & $\begin{array}{l}31.90 \pm \\
22.52^{\mathrm{a}}\end{array}$ & $\begin{array}{l}32.82 \pm \\
23.50\end{array}$ & $\begin{array}{l}32.98 \pm \\
23.32\end{array}$ & 0.029 \\
\hline $\begin{array}{l}\text { Start-up Gn } \\
\text { does(IU) }\end{array}$ & $\begin{array}{l}163.90 \pm \\
52.36\end{array}$ & $\begin{array}{l}167.20 \pm \\
56.47\end{array}$ & $\begin{array}{l}169.17 \pm \\
60.02\end{array}$ & $\begin{array}{l}157.46 \pm \\
58.74^{\mathrm{bc}}\end{array}$ & $\begin{array}{l}157.71 \pm \\
62.91\end{array}$ & 0.000 \\
\hline Total Gn dose (IU) & $\begin{array}{l}2532.36 \\
\pm 993.04\end{array}$ & $\begin{array}{l}2479.22 \pm \\
1012.23\end{array}$ & $\begin{array}{l}2529.74 \pm \\
1080.28\end{array}$ & $\begin{array}{l}2351.01 \pm \\
1083.11^{\mathrm{abc}}\end{array}$ & $\begin{array}{l}2308.48 \pm \\
1117.57\end{array}$ & 0.000 \\
\hline $\mathrm{LH}_{\text {day } 1}(\mathrm{IU} / \mathrm{L})$ & $\begin{array}{l}0.59 \pm \\
0.29\end{array}$ & $\begin{array}{l}0.72 \pm \\
0.38 a\end{array}$ & $\begin{array}{l}0.97 \pm \\
1.01^{\mathrm{ab}}\end{array}$ & $\begin{array}{l}1.06 \pm \\
0.73^{\mathrm{abc}}\end{array}$ & $\begin{array}{l}1.05 \pm \\
0.69^{\mathrm{ab}}\end{array}$ & 0.000 \\
\hline $\begin{array}{l}\text { Hormone } \\
\text { concentrations on } \\
\text { HCG }\end{array}$ & & & & & & \\
\hline
\end{tabular}

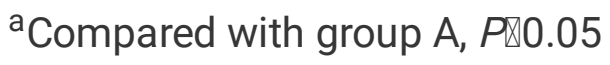

${ }^{\mathrm{b}}$ Compared with group $\mathrm{B}, P \otimes 0.05$

'Compared with group C, $P \otimes 0.05$ 


\begin{tabular}{|c|c|c|c|c|c|c|}
\hline & $\begin{array}{l}\text { Group } \\
\text { A(LH } \leq \\
0.5)\end{array}$ & $\begin{array}{l}\text { Group B } \\
(0.5 \text { 囚LH } \leq \\
1.2)\end{array}$ & $\begin{array}{l}\text { Group C } \\
(1.2 \text { ХLH } \leq \\
2)\end{array}$ & $\begin{array}{l}\text { Group D } \\
(2 \searrow L H \leq 5)\end{array}$ & $\begin{array}{l}\text { Group E } \\
\text { (LHه5) }\end{array}$ & $P$ \\
\hline $\mathrm{E} 2(\mathrm{pmol} / \mathrm{L})$ & $\begin{array}{l}1367.07 \\
\pm 6341.47\end{array}$ & $\begin{array}{l}12884.09 \pm \\
5950.26^{\mathrm{ad}}\end{array}$ & $\begin{array}{l}13131.38 \pm \\
5834.56^{\text {ad }}\end{array}$ & $\begin{array}{l}14517.02 \pm \\
6740.33^{b c}\end{array}$ & $\begin{array}{l}13151.15 \\
\pm 6015.93\end{array}$ & 0.000 \\
\hline $\mathrm{P}(\mathrm{nmol} / \mathrm{L})$ & $\begin{array}{l}3.89 \pm \\
1.42^{\mathrm{bcd}}\end{array}$ & $\begin{array}{l}3.56 \pm \\
1.44^{\text {cd }}\end{array}$ & $3.35 \pm 1.49$ & $3.21 \pm 1.42$ & $3.30 \pm 1.34$ & 0.000 \\
\hline $\begin{array}{l}\text { Endometrial } \\
\text { thickness on HCG }\end{array}$ & $\begin{array}{l}11.35 \pm \\
6.85\end{array}$ & $\begin{array}{l}11.29 \pm \\
2.26\end{array}$ & $\begin{array}{l}11.41 \pm \\
2.29^{\mathrm{ae}}\end{array}$ & $11.40 \pm 2.09$ & $\begin{array}{l}10.56 \pm \\
2.01\end{array}$ & 0.002 \\
\hline \multicolumn{7}{|c|}{${ }^{a}$ Compared with group $\mathrm{A}, P \otimes 0.05$} \\
\hline \multicolumn{7}{|c|}{${ }^{\mathrm{b}}$ Compared with group $\mathrm{B}, P \otimes 0.05$} \\
\hline${ }^{\mathrm{c} C o m p a r e d ~ w i t h ~} \subseteq$ & C, $P \otimes 0.05$ & & & & & \\
\hline
\end{tabular}

The level of $\mathrm{P}$ in groups $\mathrm{A}$ and $\mathrm{B}$ was higher than that in the other groups. The $\mathrm{AMH}$ value of group $\mathrm{C}$ was significantly lower than that of group $A$. The start-up Gn dose in group D was significantly lower than that in groups $B$ and $C$. The total $G$ dose in group $D$ was significantly lower than that in the other groups. For the hormone concentrations of $\mathrm{HCG}$, the $\mathrm{E}_{2}$ level of group $B$ and group $C$ was lower, and the $P$ level in group $A$ was the highest. On HCG day, the endometrium in group $C$ was thicker than that in groups $A$ and E (Table 1).

In terms of the numbers of retrieved eggs, embryos, high-quality embryos and diploid fertilized oocytes, an increase of the $\mathrm{LH}_{\mathrm{HCG}}$ level showed a trend of a gradual decrease. Group $\mathrm{E}$ had the highest rate of embryo transfer at the cleavage stage. However, there was no significant difference in clinical outcomes among the groups (Table 2). 
Table 2

Embryological and clinical outcomes

\begin{tabular}{|c|c|c|c|c|c|c|}
\hline & $\begin{array}{l}\text { Group } A(\mathrm{LH} \\
\leq 0.5)\end{array}$ & $\begin{array}{l}\text { Group B } \\
(0.5 \text { 囚LH } \\
\leq 1.2)\end{array}$ & $\begin{array}{l}\text { Group C } \\
(1.2 \text { खLH } \\
\leq 2)\end{array}$ & $\begin{array}{l}\text { Group D } \\
(2 \text { 贮 } \leq \\
5)\end{array}$ & $\begin{array}{l}\text { Group E } \\
\text { (LH囚5) }\end{array}$ & $P$ \\
\hline No.of oocytes & $15.22 \pm 5.66$ & $\begin{array}{l}13.54 \pm \\
5.23^{a}\end{array}$ & $\begin{array}{l}12.90 \pm \\
5.05^{\mathrm{ab}}\end{array}$ & $\begin{array}{l}12.30 \pm \\
4.88^{\mathrm{ab}}\end{array}$ & $\begin{array}{l}9.6 \pm \\
4.09^{\mathrm{abcd}}\end{array}$ & 0.000 \\
\hline $\begin{array}{l}\text { No.of diploid } \\
\text { fertilized oocytes }\end{array}$ & $9.85 \pm 4.70$ & $\begin{array}{l}8.69 \pm \\
4.41^{\mathrm{a}}\end{array}$ & $\begin{array}{l}8.39 \pm \\
4.33^{\mathrm{a}}\end{array}$ & $\begin{array}{l}7.78 \pm \\
3.96^{\mathrm{ab}}\end{array}$ & $\begin{array}{l}5.92 \pm \\
2.78^{\mathrm{abcd}}\end{array}$ & 0.000 \\
\hline No.of embryos & $7.90 \pm 4.48$ & $\begin{array}{l}6.83 \pm \\
4.03^{\mathrm{a}}\end{array}$ & $\begin{array}{l}6.44 \pm \\
3.88^{\mathrm{ab}}\end{array}$ & $\begin{array}{l}6.22 \pm \\
3.62^{\mathrm{ab}}\end{array}$ & $\begin{array}{l}4.40 \pm \\
2.55^{\mathrm{abcd}}\end{array}$ & 0.000 \\
\hline $\begin{array}{l}\text { No.of high quality } \\
\text { embryos }\end{array}$ & $4.32 \pm 3.71$ & $\begin{array}{l}3.97 \pm \\
3.42\end{array}$ & $\begin{array}{l}3.76 \pm \\
3.19\end{array}$ & $\begin{array}{l}3.71 \pm \\
3.04\end{array}$ & $\begin{array}{l}2.52 \pm \\
2.27^{\mathrm{abcd}}\end{array}$ & 0.007 \\
\hline $\begin{array}{l}\text { No.of embryos } \\
\text { transferred }\end{array}$ & $1.58 \pm 0.49$ & $\begin{array}{l}1.63 \pm \\
0.48\end{array}$ & $\begin{array}{l}1.65 \pm \\
0.48\end{array}$ & $\begin{array}{l}1.66 \pm \\
0.48\end{array}$ & $1.70 \pm 0.46$ & 0.203 \\
\hline \multicolumn{7}{|l|}{$\begin{array}{l}\text { Types of embryos } \\
\text { transferred }\end{array}$} \\
\hline $\begin{array}{l}\text { Cleavage stage } \\
\text { embryo rate }\end{array}$ & $62.22 \%$ & $68.60 \%$ & $70.03 \%$ & $70.34 \%$ & $88.33 \%^{\mathrm{abcd}}$ & 0.002 \\
\hline Blastocysts rate & $37.78 \%$ & $31.40 \%$ & $29.97 \%$ & $29.66 \%$ & $11.67 \%$ & \\
\hline OHSS rate & $3.56 \%$ & $2.80 \%$ & $3.95 \%$ & $4.66 \%$ & $6.67 \%$ & 0.090 \\
\hline $\begin{array}{l}\text { Biochemical } \\
\text { pregnancy rate }\end{array}$ & $69.33 \%$ & $67.48 \%$ & $67.56 \%$ & $68.62 \%$ & $66.67 \%$ & 0.964 \\
\hline $\begin{array}{l}\text { Clinical pregnancy } \\
\text { rate }\end{array}$ & $66.67 \%$ & $64.35 \%$ & $63.21 \%$ & $64.48 \%$ & $63.33 \%$ & 0.867 \\
\hline $\begin{array}{l}\text { Ectopic pregnancy } \\
\text { rate }\end{array}$ & $2.67 \%$ & $1.16 \%$ & $1.59 \%$ & $1.07 \%$ & 0 & 0.484 \\
\hline $\begin{array}{l}\text { Spontaneous } \\
\text { abortion rate }\end{array}$ & $10.67 \%$ & $9.64 \%$ & $8.47 \%$ & $9.09 \%$ & $2.63 \%$ & 0.509 \\
\hline Live birth rate & $56.44 \%$ & $55.58 \%$ & $54.65 \%$ & $56.03 \%$ & $60 \%$ & 0.898 \\
\hline Premature birth rate & $21.26 \%$ & $15.70 \%$ & $14.44 \%$ & $17.54 \%$ & $22.22 \%$ & 0.216 \\
\hline
\end{tabular}

Logistic regression analysis was used to determine whether the $\mathrm{LH}_{\mathrm{HCG}}$ level was related to the number of oocytes retrieved. The results showed that in the follicular-phase long protocol, with the increase in $\mathrm{LH}_{\mathrm{HCG}}$, the number of retrieved eggs decreased (Table 3 and Fig. 1). In the follicular-phase long protocol, $\mathrm{BMI}$ and $\mathrm{AMH}$ were not related to the number of eggs retrieved. 
Table 3

Linear regression analysis between serum LH concentration of HCG day and eggs retrieved

\begin{tabular}{|llll|}
\hline & Adjusted OR & $95 \% \mathrm{Cl}$ & $P$ \\
\hline LH & & & \\
\hline AgCG & -0.264 & $0.939-1.065$ & 0.000 \\
\hline BMI & -0.041 & $0.954-1.049$ & 0.006 \\
\hline Basic LH (IU/L) & -0.034 & $0.937-1.067$ & 0.060 \\
\hline AMH & -0.019 & $0.871-1.148$ & 0.192 \\
\hline Hormone concentrations on HCG & 0.000 & $0.487-2.052$ & 0.000 \\
\hline E2(pmol/L) & 0.088 & $0.559-1.788$ & 0.010 \\
\hline P(nmol/L) & 0.797 & $0.749-1.335$ & 0.000 \\
\hline P(nmol/L) & -0.034 & $0.937-1.067$ & 0.060 \\
\hline No. of $\geq 14 m m$ folliculars & -0.019 & $0.871-1.148$ & 0.192 \\
\hline
\end{tabular}

\section{Discussion}

The findings of our study suggest that the level of $\mathrm{LH}_{\mathrm{HCG}}$ can affect the IVF/ICSI outcome in the follicularphase long protocol in a young population.

The "two cell-two gonadotropin" model has been the key to our understanding of folliculogenesis (4). According to this model, LH stimulates theca cells, thereby advancing androgen production, and FSH governs the proliferation of granulosa cells (GCs) and promotes E2 synthesis. Both FSH and LH play an important role in folliculogenesis. The details of the specific role of $\mathrm{LH}$ in folliculogenesis have not been fully studied.

The follicular-phase long protocol uses a single dose of $3.75 \mathrm{mg} \mathrm{GnRH}-\mathrm{a}$ in the early follicular phase for pituitary downregulation. Two weeks after a single injection of $3.75 \mathrm{mg} \mathrm{GnRH}-\mathrm{a}$, endogenous sex hormones are almost completely inhibited. The FSH levels gradually recover after 3-4 weeks, and the $\mathrm{E}_{2}$ levels begin to rise after 7-8 weeks, whereas the inhibitory effect on LH lasts up to 8 weeks after administration (13). After 30 days, as the FSH level gradually recovers, gonadotropin (Gn) is used to stimulate the development of multiple follicles in the ovary. In the follicular-phase long protocol, due to pituitary desensitization, endogenous LH levels are very low in the later stage of stimulation. In addition, approximately $50 \%$ of patients undergoing IVF/ICSI using GnRH-A are LH deficient. Therefore, adding recombinant $\mathrm{LH}(\mathrm{rLH})$ to the process of $\mathrm{COH}$ may be beneficial to the outcome (3). Therefore, when the serum LH concentration after pituitary downregulation is between $0.5-2.5 \mathrm{U} / \mathrm{L}$, we can obtain a normal ovarian response (14). Too high or too low is not ideal. 
$\mathrm{LH}$, which is well known for its importance in the late follicular phase, supports theca cells in the ovary to provide androgens and hormonal precursors for estradiol production. LH not only promotes the growth of larger follicles but also increases FSH activity in granulosa cells by increasing androgen synthesis (15). During the development of a dominant follicle, its dependence on FSH gradually declines, whereas its dependence on LH gradually increases. FSH's partial role is replaced by LH in the late follicular phase. This facilitates the selection and maintenance of the dominant follicle.

Physiological levels of LH are clearly important for follicle development. If the LH level is abnormal, it will lead to abnormal follicular development. Therefore, it was speculated that there should be an $\mathrm{LH}$ threshold window. The Asia-Pacific consensus on the application of LH in assisted reproductive treatment published in 2011 concluded that the reasonable threshold window for LH ranges from 1.2-5 IU/L (16). However, some studies found that in the process of $\mathrm{COH}$, when the LH level was lower than 1.2 IU/L on the HCG day, it did not affect the clinical outcome (17), whereas for the follicular-phase long protocol, LH was very rarely elevated due to suppression. In this study, the LH concentration was greater than $10 \mathrm{IU} / \mathrm{L}$ in only 10 cases, and there was only 1 case with $\mathrm{LH}>20 \mathrm{IU} / \mathrm{L}$, and the $\mathrm{P}$ concentrations on the HCG day were all normal.

Our study found that in the follicular-phase long protocol, with an $\mathrm{LH} \leq 0.5 \mathrm{IU} / \mathrm{L}$ on the hCG day, patients had a higher number of oocytes retrieved, a better embryo rate, and more embryos, but there was no significant difference in the live birth rate compared with the other groups. So we speculate that when the $\mathrm{LH} \leq 0.5 \mathrm{IU} / \mathrm{L}$, although there may be pituitary hypersuppression leading to inadequate LH secretion in the late follicular phase, it does not affect the outcome. This is similar to the study of Brjercke et al. (18), that is, a lower LH can satisfy the development of follicles. As long as less than $1 \%$ of LH receptors are occupied, they can play a normal physiological role (18). However, when there are older women, a low response, a slow response, etc. in the $\mathrm{COH}$ cycle, adding $\mathrm{LH}$ may be beneficial. With a normal ovarian response, a low LH concentration does not affect the fertilization outcome (19).

However, as LH increases, the numbers of oocytes retrieved, embryos, and high-quality embryos and the number of 2PN decreased gradually, which may be because excessive LH levels may cause the ovaries to secrete more androgens, resulting in follicular atresia and then fewer oocytes retrieved. However, the pregnancy rate did not decrease, which may be because the increase in LH level only affected the number of oocytes retrieved but did not affect the quality of the oocytes, the embryo development potential or endometrial receptivity. For PGT patients, it may be more suitable to control the LH at a lower level on the HCG day to retrieve more oocytes.

The main limitations of this article are as follows: 1 . The current measurement of LH levels may not accurately reflect the true level of internal LH; 2. Our study mainly enrolled young people, which is a specific group. This may have a certain influence on the outcome; 3 . According to follicular development in the later stage, HMG or rLH may be added, which may cause the conclusion to be inaccurate. The cumulative pregnancy rate and cumulative live birth rate were not calculated. The data sample is still not large enough, and additional prospective large-sample studies are needed to confirm this idea. 
In conclusion, in the follicular-phase long protocol, the LH level is maintained at a low level throughout $\mathrm{COH}$. From the data of our study, we should pay more attention to $\mathrm{LH}_{\mathrm{HCG}}$. Elevated $\mathrm{LH}$ levels on the hCG day may lead to a reduction in oocyte retrieval. However, even when LH $\geq 5 \mathrm{IU} / \mathrm{L}$, approximately 10 oocytes are retrieved, which, for clinical purposes, is sufficient. However, those who undergo PGT may benefit more when the LH level is controlled within a certain range. Therefore, in the follicular-phase long protocol among young women, monitoring of $\mathrm{LH}_{\mathrm{HCG}}$ has clinical applications.

\section{Declarations}

\section{Acknowledgements}

The authors are grateful to physicians and coordinators who enrolled

patients and collected data all women who participated in this study.

\section{Author' contributions}

WJZ, ZZL. contributed to the conception and design of the study. MML JHL were involved in acquisition of date collection and analyzed data. YCG drafted the manuscript. All authors revised the article and gave their final approval of the submitted version.

\section{Funding}

This work has not received any external financial support from any commercial company.

\section{Availability of data and materials}

The data sets used and/or analyzed during the current study are available

from the corresponding author on reasonable request.

\section{Ethics approval and consent to participate}

The study was approved by the ethics committee of the Third Affiliated Hospital of Zhengzhou University ه2021-105》

\section{Consent for publication}

Not applicable.

\section{Conflict of interest}

The authors have nothing to disclose 


\section{References}

1. Shrestha D, La X, Feng HL. Comparison of different stimulation protocols used in in vitro fertilization: a review. Ann Transl Med. 2015;3:137.

2. Liu S, Deng C. Is LH supplementation necessary in the follicular-phase long protocol? J Reprod Med. 2018;9:29.

3. Westergaard LG, Laursen SB, Andersen CY. Increased risk of early pregnancy loss by profound suppression of luteinizing hormone during ovarian stimulation in normogonadotrophic women undergoing assisted reproduction. Hum Reprod. 2000;15:1003-8.

4. Falck B. Site of production of oestrogen in rat ovary as studied in micro-transplants. Acta Physiol Scand Suppl. 1959;47:1-101.

5. Fritz MA, Speroff L. Clinical gynecologic endocrinology and infertility. Philadelphia: Wolters Kluwer Health/Lippincott Williams \& Wilkins; 2011.

6. Balasch J, Fábregues F. Is luteinizing hormone needed for optimal ovulation induction? Curr Opin Obstet Gynecol. 2002;14:265-74.

7. Westergaard LG, Erb K, Laursen S, Rasmussen PE, Rex S. The effect of human menopausal gonadotrophin and highly purified, urine-derived follicle stimulating hormone on the outcome of invitro fertilization in down-regulated normogonadotrophic women. Hum Reprod. 1996;11:1209-13.

8. Fleming R, Lloyd F, Herbert M, Fenwick J, Griffiths T, Murdoch A. Effects of profound suppression of luteinizing hormone during ovarian stimulation on follicular activity, oocyte and embryo function in cycles stimulated with purified follicle stimulating hormone. Hum Reprod. 1998;13:1788-92.

9. Fleming R, Rehka P, Deshpande N, Jamieson ME, Yates RW, Lyall H. Suppression of LH during ovarian stimulation: effects differ in cycles stimulated with purified urinary FSH and recombinant FSH. Hum Reprod. 2000;15:1440-5.

10. Nasiri N, Eftekhari-Yazdi P. An overview of the available methods for morphological scoring of preimplantation embryos in in vitro fertilization. Cell J. 2015;16:392-405.

11. Liang X. Clinical practice and improvement of assisted reproductive technology. China: People's Health Publishing House; 2018.

12. Wu XX, Chen DL, Zheng YP. The effect of LH concentration on hCG day on the outcome of in vitro fertilization in the follicular-phase long protocol. J Huazhong Univ Sci Technol (Health Sci). 2019;48:704-7.

13. Broekmans FJ, Bernardus RE, Berkhout G, Schoemaker J. Pituitary and ovarian suppression after early follicular and mid-luteal administration of a LHRH agonist in a depot formulation: decapeptyl CR. Gynecol Endocrinol. 1992;6:153-61.

14. Alviggi C, Clarizia R, Mollo A, Ranieri A, De Placido G. Outlook: who needs LH in ovarian stimulation? Reprod Biomed Online. 2006;12:599-607.

15. Sungurtekin U, Jansen RP. Profound luteinizing hormone suppression after stopping the gonadotropin-releasing hormone-agonist leuprolide acetate. Fertil Steril. 1995;63:663-5. 
16. Wong PC, Qiao J, Ho C, Ramaraju GA, Wiweko B, Takehara Y, et al. Current opinion on use of luteinizing hormone supplementation in assisted reproduction therapy: an Asian perspective. Reprod Biomed Online. 2011;23:81-90.

17. Lossl K, Andersen AN, Loft A, Freiesleben NL, Bangsbøll S, Andersen CY. Androgen priming using aromatase inhibitor and hCG during early-follicular-phase $\mathrm{GnRH}$ antagonist down-regulation in modified antagonist protocols. Hum Reprod. 2006;21:2593-600.

18. Bjercke S, Fedorcsak P, Abyholm T, Storeng R, Ertzeid G, Oldereid N, et al. IVF/ICSI outcome and serum LH concentration on day 1 of ovarian stimulation with recombinant FSH under pituitary suppression. Hum Reprod. 2005;20:2441-7.

19. Alviggi C, Conforti A, Esteves SC, Andersen CY, Bosch E, Bühler K, et al. Recombinant luteinizing hormone supplementation in assisted reproductive technology: a systematic review. Fertil Steril. 2018;109:644-64.

\section{Figures}

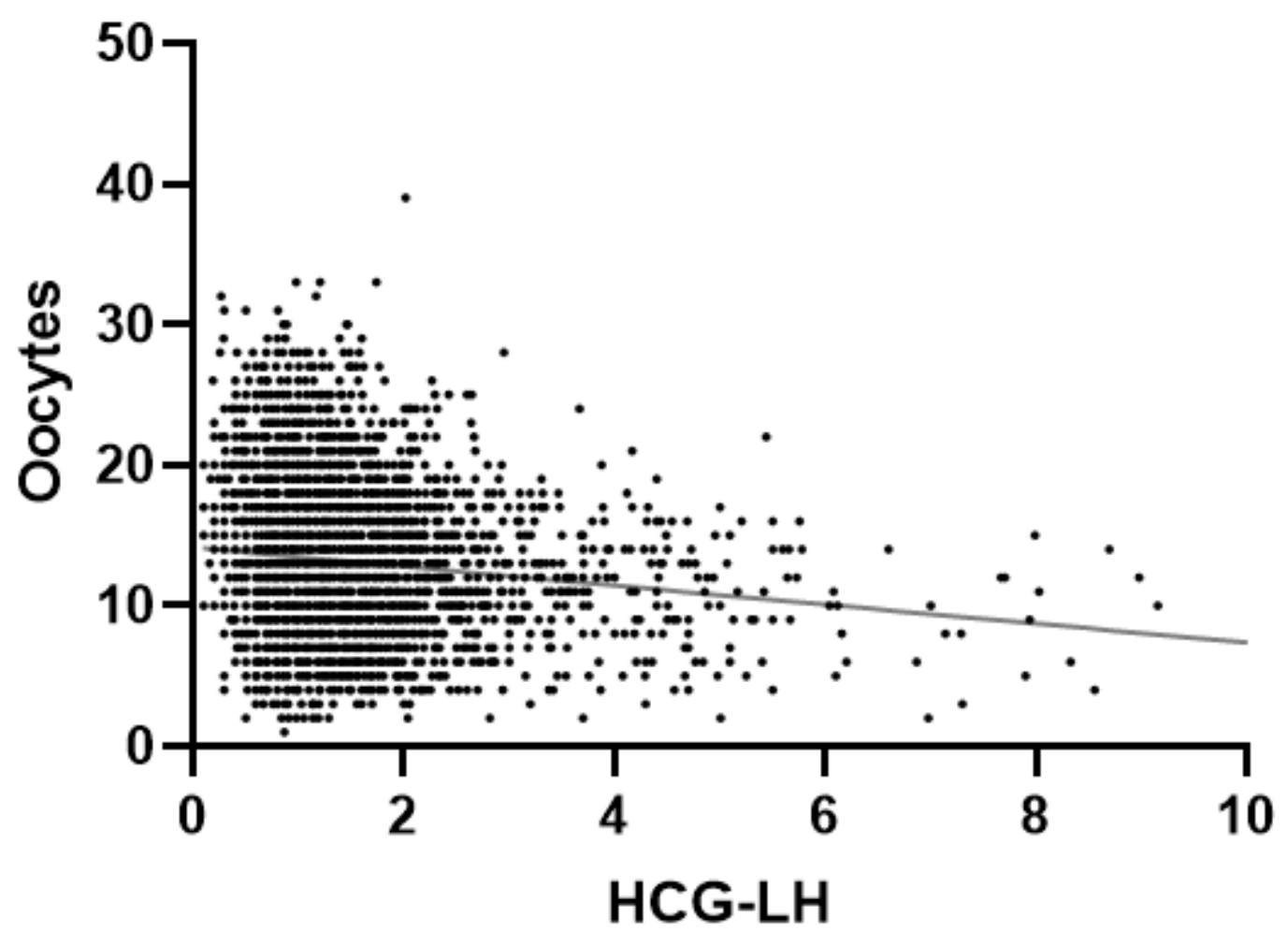

Figure 1 
Linear relationship between serum LH concentration of HCG day and eggs retrieved The Figure showed that in the follicular-phase long protocol, with the increase of LHHCG, the number of retrieved eggs decreased. 